\title{
Assessment of the antioxidant activity of an olive oil total polyphenolic fraction and hydroxytyrosol from a Greek Olea europea variety in endothelial cells and myoblasts
}

\author{
PARASKEVI KOUKA $^{1}$, ALEXANDROS PRIFTIS ${ }^{1}$, DIMITRIOS STAGOS ${ }^{1}$, \\ APOSTOLIS ANGELIS ${ }^{2}$, PANAGIOTIS STATHOPOULOS ${ }^{2}$, NIKOS XINOS ${ }^{3}$, \\ ALEXIOS-LÉANDROS SKALTSOUNIS ${ }^{2}$, CHARALAMPOS MAMOULAKIS ${ }^{4}$, \\ ARISTIDES M. TSATSAKIS ${ }^{5}$, DEMETRIOS A. SPANDIDOS ${ }^{6}$ and DEMETRIOS KOURETAS ${ }^{1}$
}

\begin{abstract}
${ }^{1}$ Department of Biochemistry and Biotechnology, University of Thessaly, 41500 Larissa; ${ }^{2}$ Department of Pharmacognosy and Natural Products Chemistry, Faculty of Pharmacy, University of Athens, 15771 Athens; ${ }^{3}$ PharmaGnose S.A., 34100 Eyboia; ${ }^{4}$ Department of Urology, University General Hospital of Heraklion, University of Crete Medical School; ${ }^{5}$ Laboratory of Toxicology, Faculty of Medicine; ${ }^{6}$ Laboratory of Clinical Virology, Medical School, University of Crete, 71003 Heraklion, Greece
\end{abstract}

Received February 2, 2017; Accepted July 3, 2017

DOI: $10.3892 /$ ijmm.2017.3078

\begin{abstract}
Olive oil (OO) constitutes the basis of the Mediterranean diet, and it seems that its biophenols, such as hydroxytyrosol (HT) may scavenge free radicals, attracting distinct attention due to their beneficial effects in many pathological conditions, such as cancer. To the best of our knowedge, this is the first study in which the functional properties of an OO total polyphenolic fraction (TPF) and pure HT were examined in order to determine their antioxidant effects at a cellular level in endothelial cells and myoblasts. The test compounds were isolated using a green gradient-elution centrifugal partition chromatography-based method that allows the isolation of large volumes of $\mathrm{OO}$ in a continuous extraction procedure and with extremely low solvent consumption. For the isolation
\end{abstract}

Correspondence to: Professor Demetrios Kouretas, Department of Biochemistry and Biotechnology, University of Thessaly, Viopolis, Larissa 41500, Greece

E-mail:dkouret@uth.gr

Abbreviations: ROS, reactive oxygen species; OOs, olive oils; $\mathrm{H}_{2} \mathrm{O}_{2}$, hydrogen peroxide; FA, fatty acid; MUFA/SFA, monounsaturated/saturated fatty acid ratio; GSH, glutathione; HT, hydroxytyrosol; EVOO, extra virgin olive oil; TPF, total polyphenolic fraction; T, tyrosol; OLEO, oleocanthal; OLEA, oleacein; DMEM, Dulbecco's modified Eagle's medium; FBS, fetal bovine serum; TLC, thin layerchromatography; $\mathrm{CPC}$, centrifugal partition chromatography; etOH, ethanol; $\mathrm{MeOH}$, methanol; ISTD, internal standard; RSC, radical scavenging capacity; ${ }^{1} \mathrm{H}-\mathrm{NMR}$, proton nuclear magnetic resonance; OD, optical density; Nrf2, nuclear factor (erythroidderived-2)-like 2

Key words: biophenols, C2C12 cells, EA.hy926 cells, hydroxytyrosol, olive oil extract, oxidative stress, reactive oxygen species of HT, a combination of two chromatographic techniques was used, which is effective for the recovery of pure compounds from complex natural extracts. Moreover, TPF and HT exhibited potent free radical scavenging activity in vitro. The cells were treated with non-cytotoxic concentrations and their redox status [in terms of glutathione (GSH) and reactive oxygen species (ROS) levels] was assessed. TPF extract was less cytotoxic than HT, and the observed differences between the two cell lines used suggest a tissue-specific activity. Finally, flow cytometric analysis revealed that both TPF and HT improved the redox status by increasing the levels of GSH, one of the most important antioxidant molecules, in both endothelial cells and myoblasts, while the ROS levels were not significantly affected.

\section{Introduction}

Aerobic organisms are exposed to reactive oxygen species (ROS) due to aerobic metabolism. ROS, such as superoxide anion $\left(\mathrm{O} 2^{\cdot-}\right)$, hydrogen peroxide $\left(\mathrm{H}_{2} \mathrm{O}_{2}\right)$ and hydroxyl radicals $\left(\mathrm{OH}^{\circ}\right)$, have coalescent chemical properties that confer reactivity to a number of biological targets (1). ROS are often associated with oxidative stress, a condition characterized by the imbalance between the production of free radicals and the endogenous antioxidant mechanisms in the favor of the first (1). ROS are capable of reversibly or irreversibly damaging biological macromolecules, such as nucleic acids, proteins, lipids and carbohydrates (1). Thus, oxidative stress may lead to the development of a number of pathological conditions, such as cancer, diabetes, obesity, and neurodegenerative and autoimmune diseases (2). However, ROS also serve as signaling molecules which regulate biological and physiological processes, such as the regulation of signaling pathways, gene expression and apoptosis (1). In living organisms, there is a wide range of endogenous defensive mechanisms against free radicals, including enzymatic and non-enzymatic antioxi- 
dants (2). Aside from the endogenous mechanisms, an organism may also acquire antioxidant components through diet $(3,4)$. Polyphenols, products of secondary metabolism in plants, are some of the most important antioxidants $(5,6)$.

The entire vascular system is comprised of a monolayer of endothelial cells. Endothelial cell integrity is necessary to the maintenance of the vessel wall and circulatory function $(7,8)$. Moreover, the endothelium regulates the homeostasis, immune and inflammatory responses (8). Oxidative stress may cause damage to the vascular endothelium due to the loss of its integrity, leading to senescence and its detachment into the circulation (9). Thus, it consists one of the most important factors of pathological conditions of vessels, including atherosclerosis and thrombosis (8). In addition, oxidative stress may cause damage to the endothelium through leukocyte adhesion $(10,11)$. Moreover, the interplay between ROS and nitric oxide sets off a vicious circle which leads to further endothelial activation and inflammation (8).

Oxidative stress also occurs in muscle tissue. Specifically, during intense exercise, a high rate of $\mathrm{O}_{2}$ consumption takes place in skeletal muscle that can cause incomplete $\mathrm{O}_{2}$ reduction and electron leakage from the electron transfer chain, leading to ROS generation and oxidative stress. Moreover, exercise induces oxidative stress through xanthine oxidase mechanisms (12). Oxidative stress, in turn, results in muscle fatigue, cell damage and apoptosis $(13,14)$.

The medicinal properties of Olea europaea (olive tree) and its main product, olive oil (OO), has been known since ancient times (15). OO is the most important component of the Mediterranean diet (16), characterized by the intake of plant foods, such as fruits, vegetables, nuts and seeds (17). Epidemiological evidence indicates an inverse association with proper adherence to this diet and death due to coronary artery disease and various types of cancer, such as urinary bladder cancer, suggesting a potential protective role of regularly consumed $\mathrm{OO}$ and its hydrophilic fraction physiologically excreted through urine (18-20). The results of in vitro studies further support this evidence by revealing a protective effect of OO against various types of cancer (21-24), including urogenital neoplasms (25-27), paving the way towards research for the development of novel anticancer strategies. It has been shown in human prostate cell cultures for example, that exposure to $\mathrm{OO}$ induces an antioxidant effect on benign prostatic hyperplasia-1 cells and a pro-oxidant effect on malignant cells, suggesting that $\mathrm{OO}$ may potentially be used for prostate cancer prevention (25). Furthermore, it has been reported that increased $\mathrm{OO}$ consumption raises the concentration of phenol glucuronide conjugates in a dose-dependent manner in human urine (28) and that extra virgin OO (EVOO) extract suppresses the migration and invasion of T24 human bladder cancer cells by significantly inhibiting proliferation/motility in a dose-dependent manner (26). These promising results have been replicated in another study showing that EVOO extract significantly inhibited the proliferation and clonogenic ability of T24 and 5637 human bladder cancer cells in a dose-dependent manner by blocking the cell cycle, and that EVOO modulated the chemotherapeutic toxicity in bladder cancer cells (27).

Over the past 25 years, the consumption of $\mathrm{OO}$ worldwide has increased by $>30 \%$ due to its two key characteristics, namely its nutritional and organoleptic properties $(16,29)$.
The nutritional properties of $\mathrm{OO}$ are provided by its fatty acid (FA) profile and high monounsaturated/saturated FA ratio (MUFA/SFA), as well as by its rich antioxidant content, particularly that of biophenols which are believed to play a role in the prevention of diseases $(16,30)$. OO biophenols act as oxidation chain-breakers, reacting with free radicals and forming inactive radicals. Some of the most important biophenols found in $\mathrm{OO}$ with marked biological activities, are oleocanthal (OLEO), oleacein (OLEA), elenoic acid, oleuropein and its derivatives, tyrosol (T) and hydroxytyrosol (HT) (31). These compounds have the ability to scavenge free radicals by donating them an electron or hydrogen atom or by chelating metals (16). Among the OO biophenols, HT has attracted distinct attention due to its potent antioxidant activity attributed mainly to its orthodiphenolic structure (32). It is mainly found in olive tree leaves, olive pulp and $\mathrm{OO}$ (33). It is worth mentioning that HT can also be synthesized endogenously in the human body, as a product of dopamine oxidative metabolism, known as 3,4-dihydroxyphenyl ethanol (DOPET) (34). HT has been shown to exert preventive effects in several pathological conditions, such as metabolic syndrome, neurodegenerative diseases and cancer (34).

The aim of the present study was to examine the antioxidant properties of a EVOO total polyphenolic fraction (TPF) rich in biophenols, from a Greek endemic variety of Olea europea, grown on Mount Athos, as well as that of pure HT. It is worth noting, that to date, at least to the best of our knowledge, there are no studies available investigating the antioxidant properties of an OO TPF in cell cultures. The antioxidants effects were assessed at a cellular level, particularly in EA.hy926 endothelial cells and $\mathrm{C} 2 \mathrm{C} 12$ myoblasts. The obtained results will provide important information on the possible use of the TPF as an antioxidant food supplement.

\section{Materials and methods}

Reagents and materials. $n$-Hexane, ethyl acetate, ethanol (etOH) and acetonitrile were purchased from Carlo Erba Reactifs SDS (Val de Reuil, France). Methanol (MeOH), dichloromethane and sulfuric acid $\left(\mathrm{H}_{2} \mathrm{SO}_{4}>95 \%\right)$ were obtained from Fisher Scientific UK (Leicestershire, UK). All solvents were of analytical grade. Deionized water was used to prepare all aqueous solutions. Vanillin standard were purchased from Sigma-Aldrich (Poole, UK) with purity of $>95 \%$.

Extraction of TPF from EVOO. EVOO was procured from Northern Greece (Mount Athos) which was freshly produced in January 2015). The extraction of TPF was achieved following a previously described procedure (35). Liquid-liquid extraction was carried out on a laboratory-scales Fast Centrifugal Partition Extractor FCPE300 ${ }^{\circledR}$ (Rousselet-Robatel Kromaton, Anonay, France; column capacity of $300 \mathrm{ml}$ ) connected to a LabAlliance preparative pump. The extraction process consisted of several 'Extraction-Recovery' cycles (multi-dual-mode method) using as 'mobile phase' a mixure of $n$-hexane/OO in proportion of $3: 2(\mathrm{v} / \mathrm{v})$ and as 'stationary phase' etOH/water in proportion of $3: 2(\mathrm{v} / \mathrm{v})$. The procedure starts by filling the CPE column with 0.3 liters of the stationary phase in ascending mode and at $200 \mathrm{rpm}$. The rotation speed was increased up to $1,000 \mathrm{rpm}$ and the mobile phase (feed oil phase) was pumped 
at $60 \mathrm{ml} / \mathrm{min}$ in ascending mode. After passing 2.5 liters of mobile phase (extraction step) the pumping mode was switched to 'descending' and a volume of 0.3 liters of aqueous extraction phase was pumped (at the same flow rate and rotation speed) in order to replace the concentrated in biophenols stationary phase with fresh one (recovery step). This cycle of extraction-recovery was repeated 5 more times extracting totally 15 liters of feed oil phase corresponding to 6 liters of OO. The 6 collected stationary phases were evaporated under a vacuum and the obtained viscous extract was defatted using the biphasic system n-hexane/ acetonitrile $(1 / 1 \mathrm{v} / \mathrm{v})$ and stored at $4^{\circ} \mathrm{C}$ for further use. Finally, the extraction of 6 liters of $\mathrm{OO}$ resulted in the recovery of $6.35 \mathrm{~g}$ of $\mathrm{OO}$ biophenol extract.

Purification of HT from TPF. High purity HT was recovered from the treatment of TPF in a two steps separation process. Initially, the extract was fractionated by gradient-elution centrifugal partition chromatography (CPC) and the enriched in the HT fraction was further analyzed by using Sephadex LH-20 (Sigma-Aldrich) column chromatography. The CPC experiment was performed on a FCPC1000 ${ }^{\circledR}$ apparatus (Rousselet-Robatel Kromaton) equipped with a preparative column (1,000 $\mathrm{ml}$ total column capacity) and connected to a LabAlliance Preparative pump. The system was coupled to a SPECTRA SYSTEM UV 2000 detector set at 254, 280 and $366 \mathrm{~nm}$ (Thermo Fisher Scientific, Inc., Waltham, MA, USA), while fractions were collected using a Büchi B-684 fraction collector (Büchi Labortechnik AG, Flawil, Switzerland).

The TPF was fractionated in a step-gradient elution mode following a previously described method (35). For this purpose, a series of 4 biphasic systems consisting of the solvents, $n$-hexane, ethyl acetate, etOH, and water in proportions 4/1/2/3 (S1), 3/2/2/3 (S2), 2/3/2/3 (S3) and 1/4/2/3 v/v/v/v (S4) were used. The solvents were thoroughly mixed in a separating funnel at room temperature prior to use, and the 2 phases of each system were separated after equilibration of the mixture. The column was initially filled with the lower phase of the first biphasic system (stationary phase) in ascending mode at a flow rate of $30 \mathrm{ml} / \mathrm{min}$ and $200 \mathrm{rpm}$. The rotation speed was increased to $1,000 \mathrm{rpm}$ and the mobile phase I (upper phase of S1) was pumped at a flow rate of $15 \mathrm{ml} / \mathrm{min}$. When the hydrodynamic equilibrium of the two liquid phases inside the CPC column was established $(\mathrm{Sf}=67 \%), 5 \mathrm{~g}$ of sample (diluted in $20 \mathrm{ml}$ of lower and $10 \mathrm{ml}$ of upper phase of S1) was injected into the column via a $30 \mathrm{ml}$ sample loop. A sequential pumping of the upper mobile phases of S1, S2, S3 and S4 was then performed in volumes of 500, 1,100, 1,400 and 1,000 ml, respectively (gradient elution step). The experiment completed by pumping the stationary phase in ascending mode (at the same flow rate and rotation speed) and collection of 30 more fractions (extrusion step). Fraction collector was set to collect $25 \mathrm{ml}$ fractions during the all experiment.

All collected fractions were evaluated using thin layer chromatography(TLC). The plates were coated(MerckMillipore, Billerica, MA, USA) with silica gel 60 F254 and developed in dichloromethane/ $\mathrm{MeOH}$ in different proportions. After detection at UV254 and UV366, the plates were sprayed with vanillin-sulfuric acid and heated. Based on the TLC qualitative results, the fractions containing HT (195 fractions of $25 \mathrm{ml}$ ) were combined and evaporated to dryness resulting to $95 \mathrm{mg}$ of an enriched HT fraction (86\% purity). For further purification, Sephadex LH-20 column chromatography was incorporated.

Specifically, $90 \mathrm{mg}$ of the sample (diluted in $1 \mathrm{ml} \mathrm{EtOH}$ ) were subjected to column chromatography (Sephadex ${ }^{\circledR}$ LH-20, 10x285 mm) and eluted with EtOH. All obtained fractions were initially analyzed by TLC and those of similar chemical content were combined giving finally three main fractions (Fractions A-C). Fraction B contained $71.3 \mathrm{mg}$ HT in high purity (>97\%). The purity was determined by quantitative high-performance liquid chromatography (HPLC) analysis.

HPLC-diode-array detection (DAD) qualitative and quantitative analysis. The qualification analysis of TPF and quantification of HT, T, OLEO and OLEA were performed on a Thermo Finnigan HPLC instrument(Ontario, Canada) equipped with a SpectraSystem P4000 pump, a SpectraSystem 1000 degasser, a SpectraSystem AS3000 automated injector, and a UV SpectraSystem UV6000LP detector monitored at 235, 280 and $365 \mathrm{~nm}$. The samples were analyzed in a Discovery HS C18 $(15 \mathrm{~cm} \times 4.6 \mathrm{~mm}$, particle size $5 \mu \mathrm{m})$ analytical column (Supelco, Bellefonte, PA, USA) using two different methods. The first one (method A) was used for the qualification analysis of the stable TPF components and quantification of HT and $\mathrm{T}$, and was based on a previously published method with minor modifications (36). Water acidified with $0.2 \%$ acetic acid (solvent A) and acetonitrile (solvent B) was used as a solvent in the following gradient system: 0-40 min 2-30\% B, 40-45 $\min 30 \% \mathrm{~B}, 45-50 \mathrm{~min} 30-2 \% \mathrm{~B}$. The flow rate was set at $1 \mathrm{ml} / \mathrm{min}$, the injection volume was $20 \mu \mathrm{l}$ (from a solution of $1 \mathrm{mg} \mathrm{TPF} / \mathrm{ml} \mathrm{MeOH}$ ) and the total run duration was $50 \mathrm{~min}$. The qualification analysis of the labile TPF components and quantification analysis of OLEA and OLEO was performed using the second method (method B). The mobile phase consisted of water (solvent A) and acetonitrile (solvent B), while the gradient elution began with $80 \%$ of solvent A decreasing to $70 \%$ in $20 \mathrm{~min}$, remaining stable for $15 \mathrm{~min}$ and increasing again to $80 \%$ in the next $5 \mathrm{~min}$ (total duration, $40 \mathrm{~min}$ ). The flow rate was set at $1 \mathrm{ml} / \mathrm{min}$, while the injection volume was $20 \mu \mathrm{l}$ (from a solution of $1 \mathrm{mg} \mathrm{TPF} / \mathrm{ml} \mathrm{MeOH}$ ), as previously described $(37,38)$.

The quantification analysis of HT and T was performed using method $\mathrm{A}$. The calibration curves were created using the concentrations 2, 3, 20, 50 and $100 \mu \mathrm{g} / \mathrm{ml}$ and was used to calculate the percentage of the target compounds in EVOO and TPF, as well as to examine the purity of HT both in CPC fraction and in the final pure form. The peak area values (measured at $280 \mathrm{~nm}$ ) constitute the average of 3 measurements. Linear regression analysis with the use of syringaldehyde (98\% HPLC; ExtraSynthese, Genay Cedex, France) as an internal standard (ISTD) was performed.

The quantification of OLEO and OLEA was performed using method $\mathrm{B}$. The calibration curves were constructed using 10 concentrations levels $(50,100,200,300,400,500,600,700$, $800,900$ and $1,000 \mu \mathrm{g} / \mathrm{ml})$. ISTD was prepared in a mixture of $\mathrm{MeOH} /$ water $1: 1(\mathrm{v} / \mathrm{v})$ at a concentration of $1 \mathrm{mg} / \mathrm{ml}$ and stored at $-4^{\circ} \mathrm{C}$. Both compounds are eluted, as double peaks and thus the quantification was based on the total area of both peaks (measured at $235 \mathrm{~nm}$ ) as previously described by Impellizzeri and Lin (37). In the case of HT and T, the quantification was based on the ratio between the peak area of the analyte 
and the peak area of ISTD. The equations and the coefficient of determination $\left(\mathrm{R}^{2}\right)$ of the standard curves were as follows: $y=45130 x+22444, R^{2}=0.995$ for OLEO, $y=43653 x-1 E+06$, $\mathrm{R}^{2}=0.997$ for OLEA, $\mathrm{y}=0.041 \mathrm{x}-0.011, \mathrm{R}^{2}=0.999$ for $\mathrm{HT}$ and $\mathrm{y}=0.025 \mathrm{x}-0,014, \mathrm{R}^{2}=0.999$ for $\mathrm{T}$.

TLC and NMR analysis. The TLC analysis of TPF and CPC fractions was performed on Merck 60 F254pre-coated silica gel plates and developed with DCM/MeOH 95:5 (v/v). The TLC chromatograms were firstly revelation by using UV light at 254 and $365 \mathrm{~nm}$ and the TLC plates were then sprayed by a vanillin $\left(5 \% \mathrm{w} / \mathrm{v}\right.$ in ethanol) $-\mathrm{H}_{2} \mathrm{SO}_{4}(50 \% \mathrm{v} / \mathrm{v}$ in methanol) solution and heated at $100-120^{\circ} \mathrm{C}$ for $2-3 \mathrm{~min}$. Structure confirmation of the isolated HT was achieved by NMR analysis. The ${ }^{1} \mathrm{H}-\mathrm{NMR}$ experiments were performed on a $600 \mathrm{MHz}$ on a Bruker AvanceAVIII-600 spectrometer (Karlsruhe, Germany) equipped with a TXI cryoprobe (Wissembourg, France) in CD3OD.

Assessment of the total polyphenolic content (TPC) of the extracts. The TPC of the OO extract was determined using the Folin-Ciocalteu reagent, as previously described (39). A total of $20 \mu \mathrm{l}$ of extract were added to a tube containing $1 \mathrm{ml}$ distilled water, followed by the addition of $100 \mu 1$ of Folin-Ciocalteu reagent and incubation for $3 \mathrm{~min}$ at room temperature. Subsequently, $280 \mu \mathrm{l}$ of $25 \% \mathrm{w} / \mathrm{v}$ sodium carbonate solution along with $600 \mu \mathrm{l}$ of distilled water were added to the mixture. Finally, following $1 \mathrm{~h}$ incubation at room temperature in the dark, the absorbance was measured at $765 \mathrm{~nm}$ versus a blank lacking the extract. The measurement was carried out on a Hitachi U-1900 radio beam spectrophotometer (serial no. 2023-029; Hitachi, Ltd., Tokyo, Japan). The optical density of the sample without the Folin-Ciocalteu reagent at $765 \mathrm{~nm}$ was also measured. The TPC was determined using a gallic acid standard curve $(50-1,500 \mu \mathrm{g} / \mathrm{ml})$. The TPC is presented as $\mu \mathrm{g}$ of gallic acid equivalents per mg of extract.

\section{2,2-diphenyl-1-picrylhydrazyl (DPPH) radical scavenging} assay. The free-radical scavenging capacity (RSC) of the TPF and HT extracts was evaluated using the DPPH radical assay (40). Briefly, a $1 \mathrm{ml}$ freshly prepared methanolic solution of DPPH radical $(100 \mu \mathrm{M})$ was mixed with the tested extract solution at various concentrations $(7.8-250 \mu \mathrm{g} / \mathrm{ml}$ TPF and $0.7-100 \mu \mathrm{g} / \mathrm{ml} \mathrm{HT}$ ). The mixture was vortexed and incubated at room temperature in the dark for $20 \mathrm{~min}$, followed by absorbance measurement at $517 \mathrm{~nm}$ on a Hitachi U-1900 radio beam spectrophotometer (serial no. 2023-029; Hitachi, Ltd.). $\mathrm{MeOH}$ was used as a blank and DPPH alone in $\mathrm{MeOH}$ was used as the control.

The percentage RSC of the tested extracts was calculated using the following equation: $\operatorname{RSC}(\%)=\left[\left(\mathrm{OD}_{\text {control }}-\mathrm{OD}_{\text {sample }}\right) /\right.$ $\left.\mathrm{OD}_{\text {control }}\right] \times 100$, where $\mathrm{OD}_{\text {control }}$ and $\mathrm{OD}_{\text {sample }}$ are the optical density (OD) values of the control and the test sample, respectively. Moreover, the $\mathrm{IC}_{50}$ value indicating the polyphenolic amount that caused 50\% scavenging of the DPPH radical was calculated. In order to compare the radical scavenging efficiency of the extracts, the specific activity was determined. The specific activity was evaluated by dividing the $\mathrm{IC}_{50}$ value obtained from the DPPHand 2,2'-Azinobis-(3-ethylbenzothiazoline-6-sulfonic acid) $\left(\mathrm{ABTS}^{\bullet+}\right)$ assays by the amount of polyphenols contained in each mg of the TPF and HT. All experiments were carried out in triplicate and on at least 3 separate occasions.

$A B T S^{\bullet+}$ radical scavenging assay. The $\mathrm{ABTS}^{\bullet+} \mathrm{RSC}$ of the extract was determined as previously described by Cano et al (41) with minor modifications. Briefly, $1 \mathrm{ml}$ reactions were prepared in distilled water containing $\operatorname{ABTS}^{\bullet+}(1 \mathrm{mM})$, $\mathrm{H}_{2} \mathrm{O}_{2}(30 \mu \mathrm{M})$ and horseradish peroxidase $(6 \mu \mathrm{M})$ in $50 \mathrm{mM}$ phosphate-buffered saline (PBS; $\mathrm{pH} 7.5$ ). The solution was vortexed, followed by incubation for $45 \mathrm{~min}$ at room temperature in the dark. Subsequently, $10 \mu 1$ of the tested extracts, at various concentrations, were added and the absorbance at $730 \mathrm{~nm}$ was read on a Hitachi U-1900 radio beam spectrophotometer (serial no. 2023-029; Hitachi, Ltd.). In each experiment, a blank lacking the peroxidase was used, while the $\mathrm{ABTS}^{\cdot+}$ radical solution without the extract was used as the control. The RSC percentage and the specific activity values were determined as described above for the DPPH method. All experiments were carried out in triplicate and on at least 3 separate occasions.

Cell culture conditions. The $\mathrm{C} 2 \mathrm{C} 12$ murine myoblasts were cultured in Dulbecco's modified Eagle's medium (DMEM), containing $10 \%$ (v/v) fetal bovine serum (FBS), $2 \mathrm{mM}$ L-glutamine, $100 \mathrm{U} / \mathrm{ml}$ of penicillin and $100 \mathrm{U} / \mathrm{ml}$ of streptomycin (all from Gibco, Paisley, UK) in plastic disposable tissue culture flasks at $37^{\circ} \mathrm{C}$ in $5 \% \mathrm{CO}_{2}$ (42). The $\mathrm{C} 2 \mathrm{C} 12$ myoblasts were donated by from Professor Koutsilieris (National and Kapodistrian University of Athens, Athens, Greece).

EA.hy926 endothelial cells were cultured as described previously in tissue culture flasks at $37^{\circ} \mathrm{C}$ in $5 \% \mathrm{CO}_{2}(34,42)$. The medium used was DMEM, containing $10 \%$ (v/v) FBS, $25 \mathrm{mM}$ HEPES, $2 \mathrm{mM}$ L-glutamine, $100 \mathrm{U} / \mathrm{ml}$ of penicillin and $100 \mathrm{U} / \mathrm{ml}$ of streptomycin (Gibco) (42). The EA.hy926 cells were donated by Professor Koukoulis (University of Thessaly, Larissa, Greece).

XTT assay. Cell viability was assessed using the XTT assay kit (Roche, Mannheim, Germany) as described previously (42). Briefly, the C2C12 and EA.hy926 cells were cultured in a 96-well plate in a density of $1 \times 10^{4}$ cells per well in DMEM. Following $24 \mathrm{~h}$ of incubation, various concentrations of the TPF and HT extracts in serum-free DMEM were administered for $24 \mathrm{~h}$. Afterwards, $50 \mu \mathrm{l}$ of XTT test solution were added to each well. Following $4 \mathrm{~h}$ of incubation, absorbance was measured at $450 \mathrm{~nm}$ and also at $630 \mathrm{~nm}$ as a reference wavelength in a BioTek ELx800 microplate reader (BioTek Instruments, Inc., Winooski, VT, USA). Serum-free DMEM was used as a negative control. In addition, the absorbance of the TPF and HT alone in serum-free DMEM and XTT test solution was measured at $450 \mathrm{~nm}$. The absorbance values of the TPF and HT alone were subtracted from those derived from cell treatment with the tested compounds. Data were calculated as the percentage of viability using the following formula: Viab ility $(\%)=\left[\left(\mathrm{OD}_{\text {control }}-\mathrm{OD}_{\text {sample }}\right) / \mathrm{OD}_{\text {control }}\right] \times 100$, where $\mathrm{OD}_{\text {control }}$ and $\mathrm{OD}_{\text {sample }}$ indicate the $\mathrm{OD}$ of the negative control and the tested compounds, respectively. All experiments were carried out in triplicate and on 3 separate occasions.

Assessment of GSH and ROS levels in cells by flow cytometry. The intracellular GSH and ROS levels were assessed using the 
fluorescent dyes, mercury orange and 2,7-dichlorofluorescein diacetate (DCF-DA), respectively (43). Mercury orange binds directly to GSH, while DCF-DA is deacetylated within cells by esterases and is further converted to fluorescent DCF by the oxidative action of ROS. A $400 \mu \mathrm{M}$ stock solution of mercury orange was prepared in acetone and stored at $4^{\circ} \mathrm{C}$, and a fresh $400 \mu \mathrm{M}$ stock solution of DCF-DA was prepared in $\mathrm{MeOH}$. To measure the GSH and ROS levels the cells were first trypsinized and centrifuged at $300 \mathrm{x}$ g for $5 \mathrm{~min}$ at $4^{\circ} \mathrm{C}$. The supernatant was discarded and the cell pellet was resuspended in PBS at $1 \times 10^{6}$ cells $/ \mathrm{ml}$ and incubated in the presence of mercury orange $(40 \mu \mathrm{M})$ or DCF-DA $(10 \mu \mathrm{M})$ in the dark at $37^{\circ} \mathrm{C}$ for $30 \mathrm{~min}$. The cells were then washed, resuspended in PBS, and subjected to flow cytometric analysis using a FACSCalibur flow cytometer (BD Biosciences, Franklin Lakes, NJ, USA) with excitation and emission wavelengths at 488 and $530 \mathrm{~nm}$ for ROS and at 488 and $580 \mathrm{~nm}$ for GSH, respectively. In addition, forward-angle and right-angle light scattering showing the cell size and cell internal complexity, respectively, were measured. The cells were analyzed at a flow rate of 1,000 events/sec. Analyses were performed on 10,000 cells per sample, and the fluorescence intensities were measured on a logarithmic scale. Data were analyzed using BD Cell Quest software (BD Biosciences). Each experiment was repeated at least 6 times.

Statistical analysis. All results are expressed as the means \pm standard error of the mean. A Spearman's correlation analysis for examining the results from the TPC, DPPH and $\mathrm{ABTS}^{\circ+}$ assays was performed. A value of $\mathrm{P}<0.05$ was considered to indicate a statistically significant difference. In addition, one-way ANOVA was applied, followed by Dunnett's tests for multiple pair wise comparisons using SPSS software (SPSS, Inc., Chicago, IL, USA).

\section{Results and Discussion}

Preliminary analysis by our research group on different EVOOs demonstrated that EVOO originating from the olive tree variety grown in Mount Athos is rich in biophenols (data not shown). Thus, this EVOO was used for the isolation of the TPF extract, as well as that of pure HT. TPF extract was also characterized chemically by determining the amount of HT, T, OLEO and OLEA biophenols. Moreover, both TPF and HT were examined for their antioxidant activity in vitro and at a cellular level in endothelial cells and myoblasts.

The recovery of the TPF was performed by applying a recently developed CPE-based extraction process which included the use of the biphasic system $n$-hexane/ EVOO/etOH/water-3/2/3/2 v/v/v/v and a multiple dual-mode $\mathrm{CPE}$ method for the treatment of $\mathrm{OO}(27,35)$. Compared to other purposed OO extraction methods $(44,45)$, this green process allows the treatment of large volumes of $\mathrm{OO}$ in a continuous extraction procedure and with extremely low solvent consumption. Thus, 6 extraction-recovery cycles were performed by pumping per each cycle 2.5 liters of feed oil phase (at $60 \mathrm{ml} / \mathrm{min}$ in ascending mode) and replacing the concentrated in biophenols stationary phase with $300 \mathrm{ml}$ of fresh aqueous extraction phase (see experimental part). It is important to note that the treatment by this process of 6 liters of $\mathrm{OO}$ (corresponding to $5,478 \mathrm{~g}$ ) resulted the recovery of $6.35 \mathrm{~g}$ of TPF in only $5 \mathrm{~h}$. However, due to the high complexity of TPF the first step of the separation process included a step-gradient CPC fractionation with a series of four biphasic systems consisting of the solvents $n$-hexane, ethyl acetate, etOH and water in proportions 4/1/2/3 (S1), 3/2/2/3 (S2), $2 / 3 / 2 / 3$ (S3) and $1 / 4 / 2 / 3 \mathrm{v} / \mathrm{v} / \mathrm{v} / \mathrm{v}$ (S4) $(27,35)$. Even if this method afforded approximately HT in $87 \%$ purity, an additional purification step was required and therefore size exclusion column chromatography was used. The combination of these two chromatographic techniques has the advantage of using different criteria of selectivity between two purification steps and has been successfully applied for the recovery of pure compounds from complex natural extracts (46). The result of this two-step purification procedure was the effective recovery of high purity $(>97 \%)$ HT. The purity of the recovered compounds was firstly examined by proton nuclear magnetic resonance ( $\left.{ }^{1} \mathrm{H}-\mathrm{NMR}\right)$ and was then evaluated by HPLC-DAD analysis.

In addition, since the compounds under investigation behave differently in the presence or absence of acid two different elution systems have been used. Specifically, for the analysis of the TPF constituents, such as the phenyl alcohols (HT and T), the mobile phase of the used HPLC method (method A, see Materials and methods) contained acidified solvent (water acidified with $0.2 \%$ acetic acid) in order to increase the quality of the analysis. On the other hand, OLEA and OLEO are labile components and they are not stable in acidic conditions. Thus, the mobile phase of the HPLC method (method B, see Materials and methods) used for the analysis of those compounds was composed of water (solvent A) and acetonitrile (solvent B) without acidification. The profiling of TPF as resulting from HPLC-DAD chromatograms is depicted in Fig. 1. The results of the quantitative analysis are expressed in $\mathrm{mg} / \mathrm{g}$ TPF. Specifically, TPF extract contained $19.4 \mathrm{mg} / \mathrm{g} \mathrm{HT}$, $24.4 \mathrm{mg} / \mathrm{g} \mathrm{T}, 56.3 \mathrm{mg} / \mathrm{g}$ OLEA and $135.5 \mathrm{mg} / \mathrm{ml}$ OLEO.

As indicated by the quantitative analysis, the TPF was rich in biophenols. Specifically, the TPC as measured by Folin-Ciocalteau assay was $484 \mu \mathrm{g}$ of biophenols per $\mathrm{mg}$ of TPF extract. According to a comparative study in which 221 EVOOs were extracted from 4 olive mono-cultivars (Koroneiki, Tsounati, Adramitini, and Throubolia) originating from 4 divisions of Greece (47), the range of TPC was between $30-351 \mathrm{mg} / \mathrm{kg}$ EVOOs. Of note, according to a health claim on OO polyphenols approved by the European Food Safety Authority (EFSA; Commission Regulation EU 432/2012), OOs are considered to protect from oxidative stress-induced lipid peroxidation in blood, when they contain about $5 \mathrm{mg}$ of HT and its derivatives (e.g., oleuropein complex and T) per $20 \mathrm{~g}$ of OO. Based on the content of TPF in biophenols, OO in the present study, contain $4.15 \mathrm{mg}$ of $\mathrm{HT}$ and its derivatives per $20 \mathrm{~g}$.

The chemical analysis of TPF indicated that the T levels were high $(28.28 \mathrm{mg} / \mathrm{kg}$ TPF $)$ and close to those of HT $(22.48 \mathrm{mg} / \mathrm{kg}$ $\mathrm{TPF}$ ), according to a comparative study, where the T levels fluctuated between $1.97-16.2 \mathrm{mg} / \mathrm{kg}$ OO (47). Additionally, OLEO exhibited the highest concentration which was $>2$-fold higher than that of OLEA.

Following the determination of the biophenolic content, the antioxidant activities of TPF and HT were evaluated by DPPH and $\mathrm{ABTS}^{-+}$assays (Fig. 2). In order to examine the antioxidant potency of the biophenols contained in the tested compounds, 

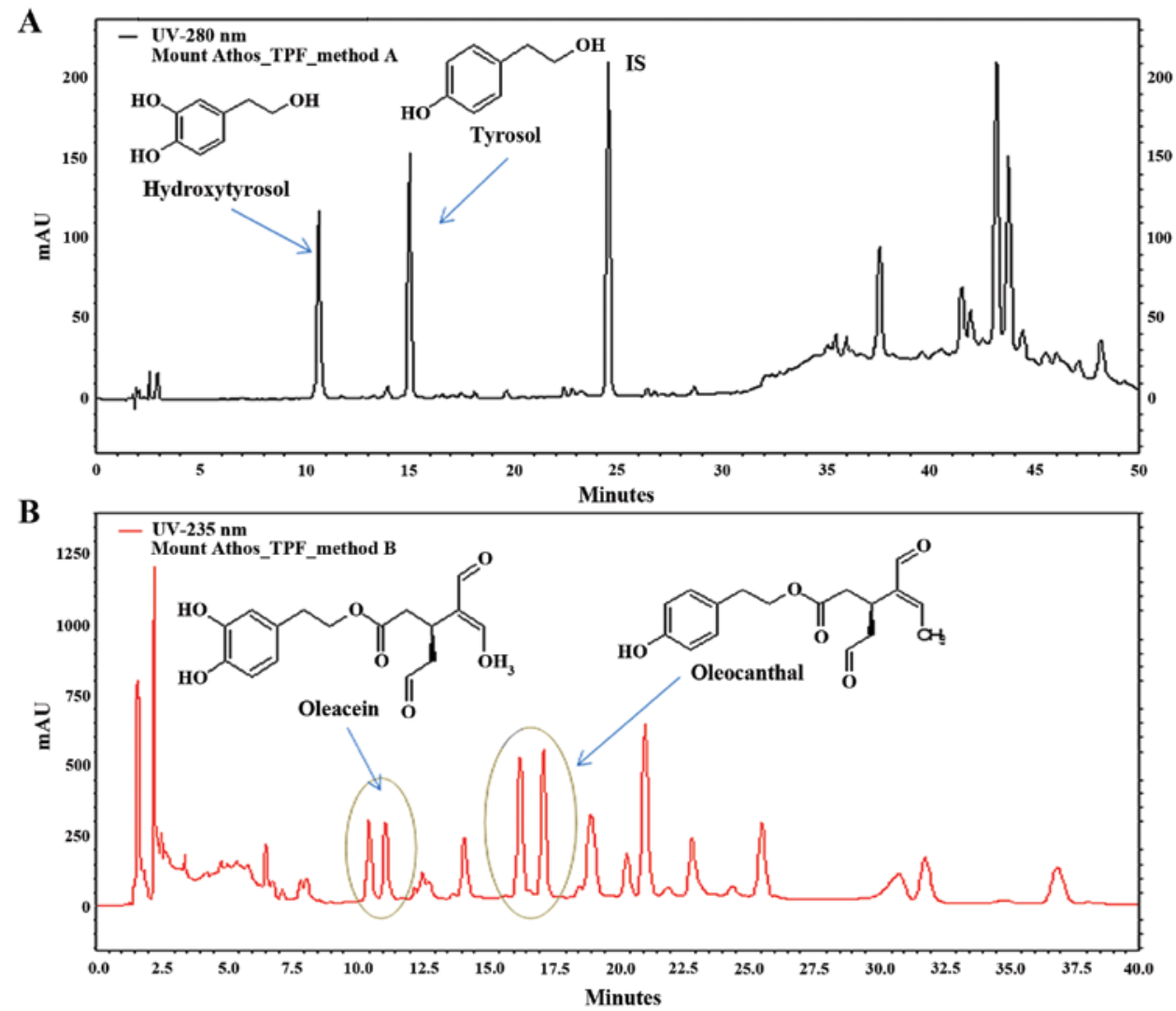

Figure 1. HPLC-DAD chromatograms of TPF. (A) Chromatogram recorded with method A suitable for the analysis of HT and T. (B) Chromatogram recorded with HPLC method B suitable for the analysis of OLEA and OLEO. OLEA and OLEO are eluted, as double peaks. HPLC-DAD, high-performance liquid chromatography-diode-array detection; TPF, total polyphenolic fraction; HT, hydroxytyrosol; T, tyrosol; OLEA, oleacein; OLEO, oleocanthal.

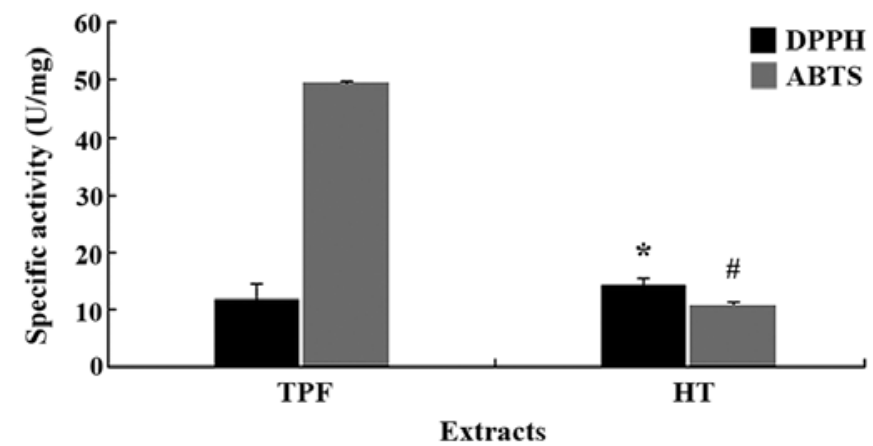

Figure 2. Antioxidant activity as assessed using DPPH and $\mathrm{ABTS}^{*+}$ assays. The specific activity of each test compound is shown, as measured in units of activity per mg of TPF and HT. A unit represents the amount of biophenols required to scavenge $50 \%$ of DPPH and $\mathrm{ABTS}^{++}$radicals. The TPF concentrations expressed as polyphenol content divided to TPC. All data are expressed as the means \pm standard error of the mean of 3 experiments $(n=3)$. ${ }^{*} \mathrm{P}<0.05$ indicated a statistically significant difference between TPF and HT in the DPPH method and ${ }^{\#} \mathrm{P}<0.05$ in the $\mathrm{ABTS}^{\cdot+}$ method. TPF, total polyphenolic fraction; HT, hydroxytyrosol.

the specific activity was determined. Specific activity is a unit that compares extracts with varying composition. Since HT was a pure polyphenol, for the calculation of the specific activity, its polyphenolic content was considered as $100 \%$. According to DPPH assay, HT exhibited a significantly $(\mathrm{P}<0.05)$ higher antioxidant activity compared with TPF. by contrast, in ABTS ${ }^{\circ+}$ assay, the antioxidant activity of HT was significantly $(\mathrm{P}<0.05)$ lower than that of TPF. These differences between the DPPH and
$\mathrm{ABTS}^{\bullet+}$ assays may be ascribed to the different solvents used in each assay (48). In particular, in DPPH assay the solvent is $\mathrm{MeOH}$ while in $\mathrm{ABTS}^{\circ+}$ assay the solvent is water (49). Namely, the bioactive compounds of TPF may be more polar and so they were dissolved more in water and less in $\mathrm{MeOH}$ than HT.

The antioxidant activity of the tested compounds was also examined in C2C12 myoblasts and EA.hy926 endothelial cells. In order to use non-cytotoxic concentrations of the tested compounds for these experiments, their cytotoxicity was assessed by XTT assay. The results from XTT assay revealed that TPF exhibited cytotoxicity at concentrations $>24.0 \mu \mathrm{g} / \mathrm{ml}$ in both the $\mathrm{C} 2 \mathrm{C} 12$ and EA.hy926 cells (Fig. 3A and B). HT exerted cytotoxic effects at concentrations $>30.0 \mu \mathrm{g} / \mathrm{ml}$ in the $\mathrm{C} 2 \mathrm{C} 12$ cells and $>2.5 \mu \mathrm{g} / \mathrm{ml}$ in the EA.hy926 cells (Fig. 3C and D). Thus, the range of concentrations used for assessing the antioxidant activity of the tested compounds were 2.5-10.0 $\mu \mathrm{g} / \mathrm{ml}$ for TPF in both the $\mathrm{C} 2 \mathrm{C} 12$ and EA.hy926 cells, and $10-25$ and $0.25-1.0 \mu \mathrm{g} / \mathrm{ml}$ for HT in the $\mathrm{C} 2 \mathrm{C} 12$ and EA.hy926 cells, respectively.

The results from flow cytometric analysis revealed that treatment of the $\mathrm{C} 2 \mathrm{C} 12$ cells with TPF significantly increased the GSH levels by $26,28,37$ and $23 \%$ at $2.5,5,7.5$ and $10 \mu \mathrm{g} / \mathrm{ml}$, respectively, compared with control (Fig. 4A). Treatment of the $\mathrm{C} 2 \mathrm{C} 12$ cells with HT also significantly increased the GSH levels by $24,23,54$ and $38 \%$ at 10, 15, 20 and $25 \mu \mathrm{g} / \mathrm{ml}$, respectively (Fig. 4B). Moreover, treatment of the EA.hy 926 cells with TPF and HT significantly increased the GSH levels compared to the controls (Fig. 4C and D). Thus, the effects of TPF and HT on the GSH levels seemed to be cell type-independent. Particularly, 
A

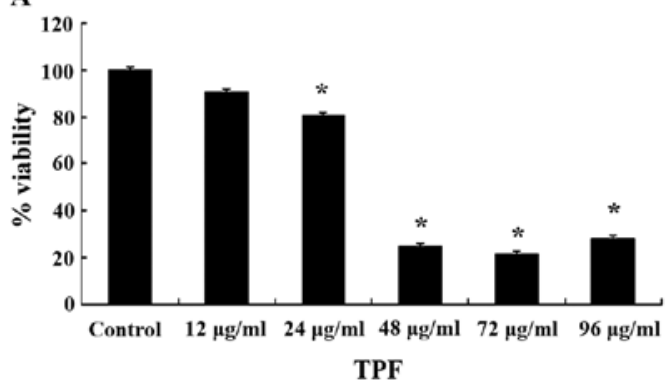

C

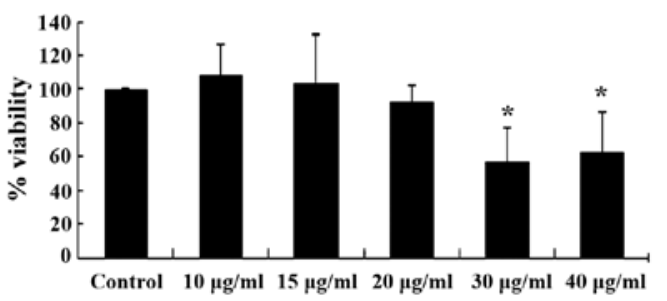

HT

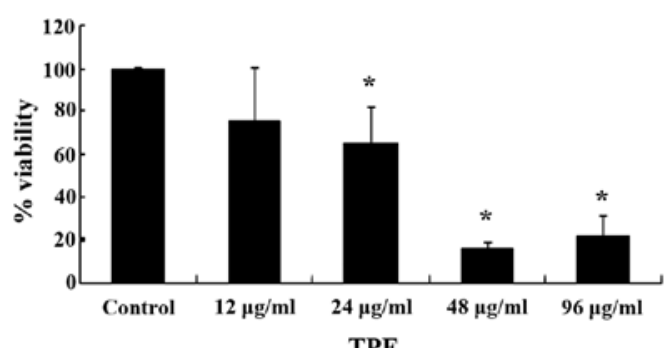

D

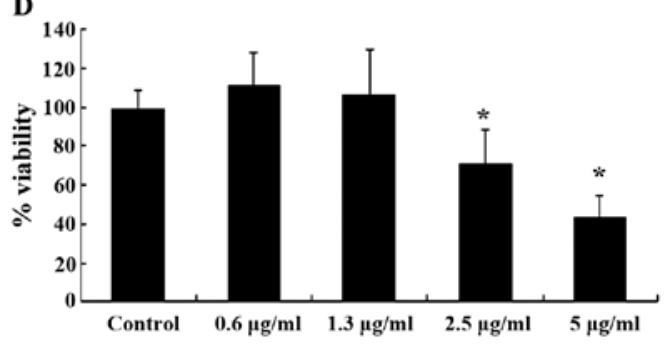

HT

Figure 3. Assessment of the effects of tested compounds on the viability of $\mathrm{C} 2 \mathrm{C} 12$ myoblasts and EA.hy 926 endothelial cells after $24 \mathrm{~h}$ of treatment by XTT assay. (A) Cytotoxicity of TPF in C2C12 cells. (B) Cytotoxicity of TPF in EA.hy926 cells. (C) Cytotoxicity of HT in C2C12 cells. (D) Cytotoxicity of HT in EA.hy926 cells. The TPF concentrations expressed as polyphenol content divided to TPC. All data are expressed as the means \pm standard error of the mean of 6 experiments $(\mathrm{n}=6)$. " $\mathrm{P}<0.05$ indicated a statistically significant difference compared to the control. TPF, total polyphenolic fraction; HT, hydroxytyrosol; TPC, total phenolic content.
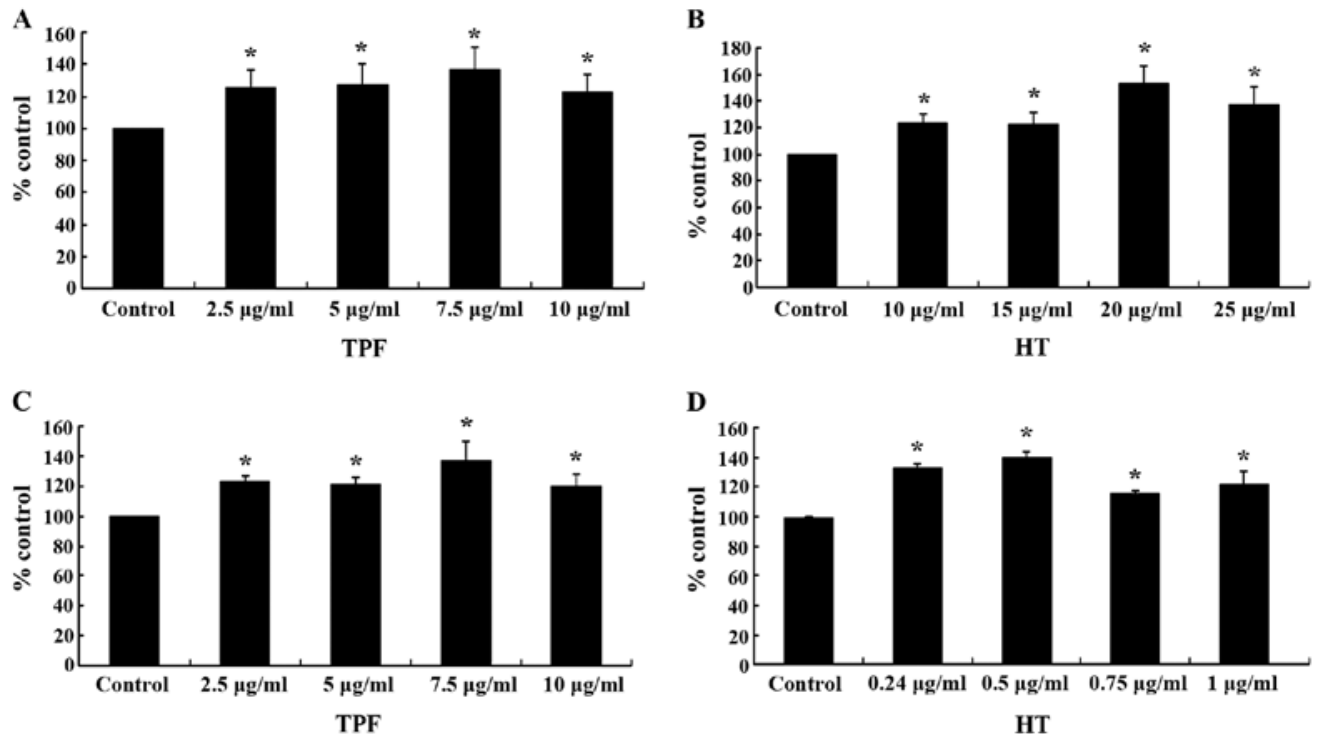

Figure 4. Effects of the test compounds on GSH levels in C2C12 myoblasts and EA.hy 926 cells after treatment for 24 h, as assessed by flow cytometry. (A) Effects of TPF extract on C2C12 cells. (B) Effects of HT on C2C12 cells. (C) Effects of TPF extract on EA.hy926 cells. (D) Effects of HT on EA.hy926 cells. Bar charts showing the GSH levels, as calculated by BD Cell Quest software. The TPF concentrations expressed as polyphenol content divided to TPC. All results are expressed as the means \pm standard error of the mean of 6 experiments $(n=6) .{ }^{*} \mathrm{P}<0.05$ indicated a statistically significant difference between TPF or HT concentrations and the control. TPF, total polyphenolic fraction; HT, hydroxytyrosol; GSH, glutathione; TPC, total phenolic content.

TPF increased the GSH levels in the EA.hy926 cells by 23, 22, 38 and $20 \%$ at $2.5,5,7.5$ and $10 \mu \mathrm{g} / \mathrm{ml}$, respectively, while HT by $34,40,15$ and $22 \%$ at $0.25,0.5,0.75$ and $1.0 \mu \mathrm{g} / \mathrm{ml}$ respectively, compared to controls (Fig. 4C and D). The HT-induced increase in GSH levels suggested that this polyphenol was one of the bioactive compounds in TPF accounting for its effects on the GSH levels.

HT has been shown to increase GSH synthesis in human retinal pigment epithelial cells by the activation of the nuclear factor (erythroid-derived-2)-like 2 (Nrf2), a transcription factor and a key regulator of the antioxidant defense system (Fig. 6) (50-53). Nrf2 induces the expression of gamma-glutamylcysteine ligase (GCL), which has the ability to regulate the synthesis of GSH (54). Moreover, HT seems to activate the NK-p62/SQSTM1 pathway, required for Nrf2-induced GSH synthesis $(42,50)$. Manzanares et al (55) indicated that after a high EVOO diet, the activation of Nrf2 was observed in rat livers and mammary glands. 

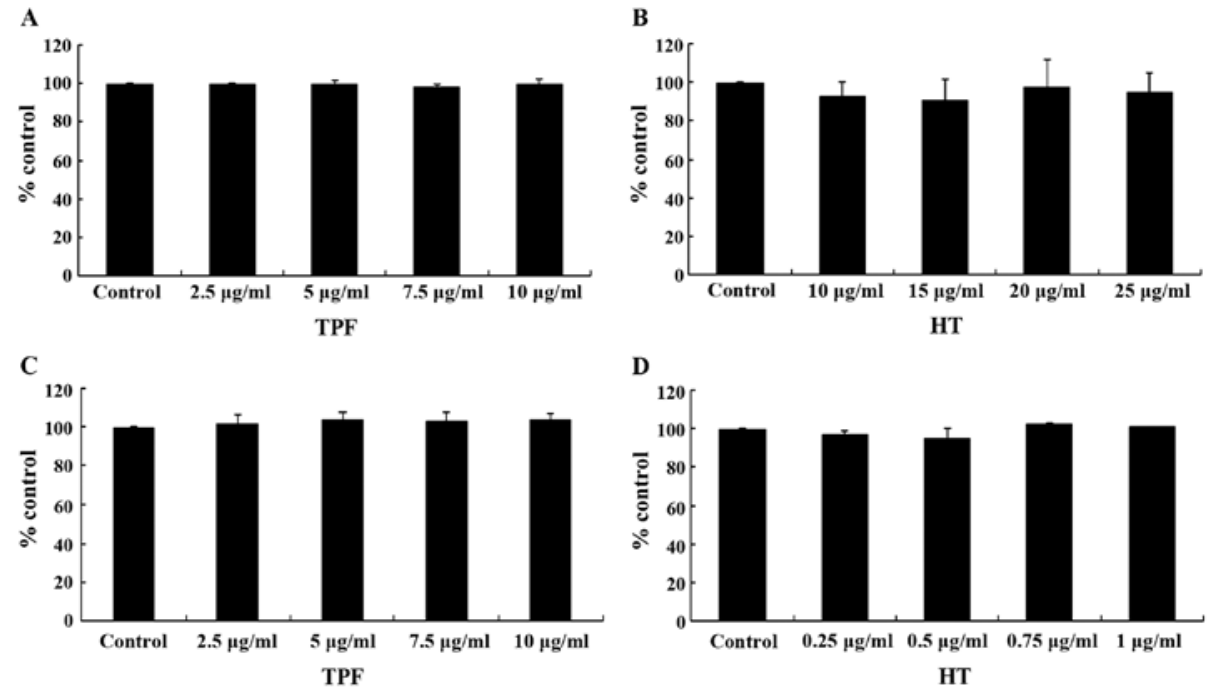

Figure 5. Effects of the test compounds on ROS levels in C2C12 myoblasts and EA.hy926 cells after treatment for $24 \mathrm{~h}$, as assessed by flow cytometry. (A) Effects of TPF extract on C2C12 cells. (B) Effects of HT on C2C12 cells. (C) Effects of TPF extract on EA.hy926 cells. (D) Effects of HT on EA.hy926 cells. Bar charts showing the ROS levels, as calculated by BD Cell Quest software. All results are expressed as the means \pm standard error of the mean of 6 experiments (n=6). ${ }^{*} \mathrm{P}<0.05$ indicated a statistically significant difference between TPF or HT concentrations and the control. The TPF concentrations expressed as polyphenol content divided to TPC. TPF, total polyphenolic fraction; HT, hydroxytyrosol; ROS, reactive oxygen species; TPC, total phenolic content.

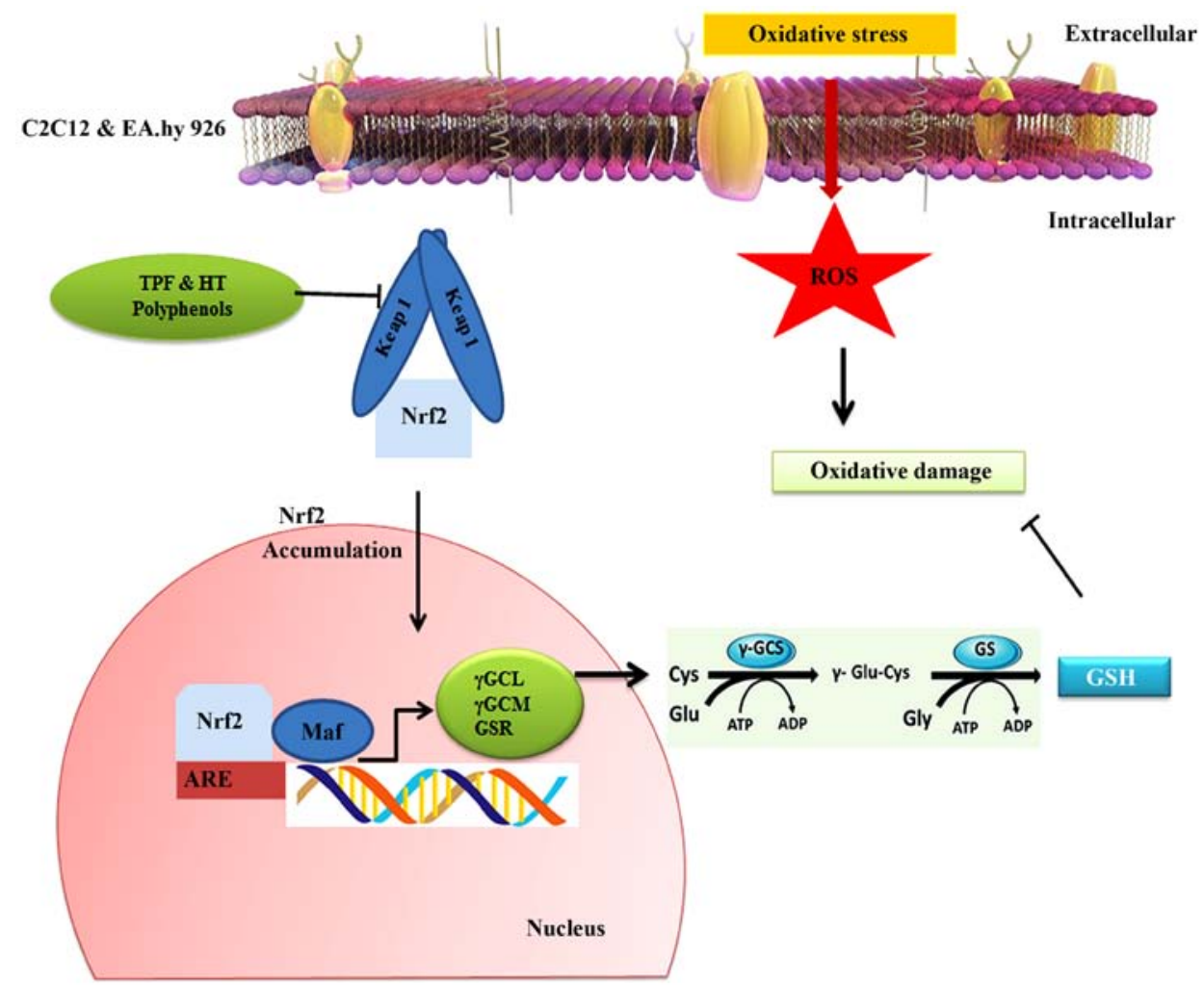

Figure 6. Possible mechanisms through which TPF and HT exert their effects on GSH levels. TPF, total polyphenolic fraction; HT, hydroxytyrosol; Nrf2, nuclear factor (erythroid-derived-2)-like 2; ROS, reactive oxygen species; GSH, glutathione; ARE, antioxidant response element.

Moreover, OO biophenols, from olive mill waste water have been shown to increase GSH concentrations in human blood $(48,56)$. This increase in GSH levels may be due to the upregulation of GCL and GSH synthetase, mediated by the antioxidant response element (ARE; a target of Nrf2) (Fig. 6) (56). Covas et al indicated that an EVOO rich in biophenols $(366 \mathrm{mg} / \mathrm{kg})$ beneficially modulated the balance between GSH and oxidized glutathione (GSSG). Thus, EVOO biophenols exert their antioxidant effects as a part of the induction of Nrf2 (57).

It is also worth mentioning that at the highest concentration, both TPF and HT exhibited less potency for increasing the GSH levels than at lower concentrations. This observed decrease in the potency of TPF and HT at the highest concentrations may be explained by a potential pro-oxidant activity of polyphenols 
after reaching a 'crucial' concentration (43,58-61). A potential pro-oxidant activity was also supported by the cytotoxicity exerted by TPF and HT after these high concentrations.

Oleuropein and HT have been reported to exert pro-oxidant effects, due to their iron- and copper-reducing activities. These reduced metals, in turn, can catalyze the production of $\mathrm{OH}^{-}$ radicals by the Fenton reaction. The ability of dietary polyphenols to act as antioxidants/prooxidants under in vitro and in vivo systems is dependent on a number of factors such their concentration and structure (62).

The observed TPF- and HT-induced increase in GSH levels in $\mathrm{C} 2 \mathrm{C} 12$ myoblasts and EA.hy926 endothelial cells is of importance. GSH is a conserved molecule among many species, reflecting its crucial biological role. In particular, it has been established that the thiol moiety of GSH is important for the direct scavenging of radical species (63). Thus, a decrease at GSH levels contributes to oxidative stress associated with aging and many pathological conditions, such as neurodegenerative diseases, inflammation, and infections (63).

Unlike GSH, the ROS levels were not significantly affected by the two test compounds compared to the controls in neither cell line (Fig. 5). It should be mentioned that the measured ROS levels corresponded to the naturally occurring levels in these cells; that is, there was not any treatment of cells with oxidizing agents before the addition of TPF and HT. Previous studies have also reported that changes in oxidative stress levels or antioxidant mechanisms are not always accompanied by changes in ROS levels $(42,43,64)$.

In conclusion, EVOO from a Greek endemic olive tree variety, Olea europea, was used for the isolation of TPF, as well as that of pure HT. For the extraction process, it was used a recently developed green CPE-based method that allows the treatment of large volumes of $\mathrm{OO}$ in a continuous extraction procedure and with extremely low solvent consumption. For the isolation of pure HT, a combination of two chromatographic techniques was used, which has the advantage of using different criteria of selectivity between two purification steps and thus it is effective for the recovery of pure compounds from complex natural extracts. As indicated from the quantitative analysis, the TPF extract was rich in biophenols, such as T, HT, OLEO and OLEA. Finally, TPF and HT exhibited in vitro potent free radical scavenging activity, while they increased (at low concentrations), the levels of GSH, one of the most important antioxidant molecules, in both endothelial cells and myoblasts.

\section{Acknowledgements}

The present study was funded in part by a grant (Demetrios Kouretas) from the 'Tsantali Wineries'.

\section{References}

1. Schieber M and Chandel NS: ROS function in redox signaling and oxidative stress. Curr Biol 24: R453-R462, 2014.

2. Pham-Huy LA, He H and Pham-Huy C: Free radicals, antioxidants in disease and health. Int J Biomed Sci 4: 89-96, 2008.

3. Landete JM: Dietary intake of natural antioxidants: Vitamins and polyphenols. Crit Rev Food Sci Nutr 53: 706-721, 2013.

4. Fang YZ, Yang S and Wu G: Free radicals, antioxidants, and nutrition. Nutrition 18: 872-879, 2002.

5. Landete JM: Updated knowledge about polyphenols: functions, bioavailability, metabolism, and health. Crit Rev Food Sci Nutr 52: 936-948, 2012.
6. Li HY, Yang M, Li Z and Meng Z: Curcumin inhibits angiotensin II-induced inflammation and proliferation of rat vascular smooth muscle cells by elevating PPAR- $\gamma$ activity and reducing oxidative stress. Int J Mol Med 39: 1307-1316, 2017.

7. Kerasioti E, Stagos D, Georgatzi V, Bregou E, Priftis A, Kafantaris I and Kouretas D: Antioxidant effects of sheep whey protein on endothelial cells. Oxid Med Cell Longev 2016: 6585737, 2016.

8. Deanfield JE, Halcox JP and Rabelink TJ: Endothelial function and dysfunction: Testing and clinical relevance. Circulation 115: 1285-1295, 2007

9. Woywodt A, Bahlmann FH, De Groot K, Haller H and Haubitz M: Circulating endothelial cells: Life, death, detachment and repair of the endothelial cell layer. Nephrol Dial Transplant 17: 1728-1730, 2002.

10. Kokura S, Wolf RE, Yoshikawa T, Granger DN and Aw TY: Molecular mechanisms of neutrophil-endothelial cell adhesion induced by redox imbalance. Circ Res 84: 516-524, 1999.

11. Zou Y, Yoon S, Jung KJ, Kim CH, Son TG, Kim MS, Kim YJ, Lee J, Yu BP and Chung HY: Upregulation of aortic adhesion molecules during aging. J Gerontol A Biol Sci Med Sci 61: 232-244, 2006.

12. Spanou C, Veskoukis AS, Kerasioti T, Kontou M, Angelis A Aligiannis N, Skaltsounis AL and Kouretas D: Flavonoid glycosides isolated from unique legume plant extracts as novel inhibitors of xanthine oxidase. PLoS One 7: e32214, 2012.

13. Goutzourelas N, Stagos D, Spanidis Y, Liosi M, Apostolou A, Priftis A, Haroutounian S, Spandidos DA, Tsatsakis AM and Kouretas D: Polyphenolic composition of grape stem extracts affects antioxidant activity in endothelial and muscle cells. Mol Med Rep 12: 5846-5856, 2015.

14. Reid MB: Free radicals and muscle fatigue: Of ROS, canaries, and the IOC. Free Radic Biol Med 44: 169-179, 2008.

15. Rafehi H, Smith AJ, Balcerczyk A, Ziemann M, Ooi J, Loveridge SJ, Baker EK, El-Osta A and Karagiannis TC: Investigation into the biological properties of the olive polyphenol, hydroxytyrosol: Mechanistic insights by genome-wide mRNA-Seq analysis. Genes Nutr 7: 343-355, 2012.

16. Montaño A, Hernández M, Garrido I, Llerena JL and Espinosa F: Fatty acid and phenolic compound concentrations in eight different monovarietal virgin olive oils from extremadura and the relationship with oxidative stability. Int J Mol Sci 17: 17, 2016.

17. Local Food-Nutraceuticals Consortium: Understanding local Mediterranean diets: a multidisciplinary pharmacological and ethnobotanical approach. Pharmacol Res 52: 353-366, 2005.

18. Trichopoulou A, Costacou T, Bamia C and Trichopoulos D: Adherence to a Mediterranean diet and survival in a Greek population. N Engl J Med 348: 2599-2608, 2003.

19. Trichopoulou A, Lagiou P, Kuper $H$ and Trichopoulos D: Cancer and Mediterranean dietary traditions. Cancer Epidemiol Biomarkers Prev 9: 869-873, 2000.

20. Brinkman MT, Buntinx F, Kellen E, Van Dongen MC Dagnelie PC, Muls E and Zeegers MP: Consumption of animal products, olive oil and dietary fat and results from the Belgian case-control study on bladder cancer risk. Eur J Cancer 47: 436-442, 2011.

21. Oliveras-Ferraros C, Fernández-Arroyo S, Vazquez-Martin A, Lozano-SánchezJ,Cufí S, Joven J,Micol V, Fernández-Gutiérrez A, Segura-Carretero A and Menendez JA: Crude phenolic extracts from extra virgin olive oil circumvent de novo breast cancer resistance to HER1/HER2-targeting drugs by inducing GADD45-sensed cellular stress, G2/M arrest and hyperacetylation of Histone H3. Int J Oncol 38: 1533-1547, 2011.

22. Tunca B, Tezcan G, Cecener G, Egeli U, Ak S, Malyer H, Tumen G and Bilir A: Olea europaea leaf extract alters microRNA expression in human glioblastoma cells. J Cancer Res Clin Oncol 138: 1831-1844, 2012.

23. Bouallagui Z, Han J, Isoda H and Sayadi S: Hydroxytyrosol rich extract from olive leaves modulates cell cycle progression in MCF-7 human breast cancer cells. Food Chem Toxicol 49: 179-184, 2011.

24. Cárdeno A, Sánchez-Hidalgo M, Cortes-Delgado A and Alarcón de la Lastra C: Mechanisms involved in the antiproliferative and proapoptotic effects of unsaponifiable fraction of extra virgin olive oil on HT-29 cancer cells. Nutr Cancer 65: 908-918, 2013.

25. Acquaviva R, Di Giacomo C, Sorrenti V, Galvano F, Santangelo R, Cardile V, Gangia S, D'Orazio N, Abraham NG and Vanella L: Antiproliferative effect of oleuropein in prostate cell lines. Int J Oncol 41: 31-38, 2012. 
26. Coccia A, Bastianelli D, Mosca L, Monticolo R, Panuccio I Carbone A, Calogero A and Lendaro E: Extra virgin olive oil phenols suppress migration and invasion of T24 human bladder cancer cells through modulation of matrix metalloproteinase- 2 . Nutr Cancer 66: 946-954, 2014.

27. Coccia A, Mosca L, Puca R, Mangino G, Rossi A and Lendaro E: Extra-virgin olive oil phenols block cell cycle progression and modulate chemotherapeutic toxicity in bladder cancer cells Oncol Rep 36: 3095-3104, 2016.

28. Miró-Casas E, Covas MI, Fitó M, Farré-Albadalejo M, Marrugat $\mathbf{J}$ and de la Torre R: Tyrosol and hydroxytyrosol are absorbed from moderate and sustained doses of virgin olive oil in humans. Eur J Clin Nutr 57: 186-190, 2003.

29. Keys A, Menotti A, Karvonen MJ, Aravanis C, Blackburn H, Buzina R, Djordjevic BS, Dontas AS, Fidanza F, Keys MH, et al The diet and 15-year death rate in the seven countries study. Am J Epidemiol 124: 903-915, 1986.

30. Obied HK, Prenzler PD, Omar SH, Ismael R, Servili M, Esposto S, Taticchi A, Selvaggini R and Urbani S: Pharmacology of Olive Biophenols. In: Advances in Molecular Toxicology. Fishbein JC and Heilman JM (eds). Vol 6. Elsevier, Amsterdam, pp195-242, 2012

31. Lewandowska U, Szewczyk K, HrabecE, Janecka A and Gorlach S: Overview of metabolism and bioavailability enhancement of polyphenols. J Agric Food Chem 61: 12183-12199, 2013.

32. Schaffer S, Podstawa M, Visioli F, Bogani P, Müller WE and Eckert GP: Hydroxytyrosol-rich olive mill wastewater extract protects brain cells in vitro and ex vivo. J Agric Food Chem 55: 5043-5049, 2007.

33. Rietjens SJ, Bast A and Haenen GR: New insights into controversies on the antioxidant potential of the olive oil antioxidant hydroxytyrosol. J Agric Food Chem 55: 7609-7614 2007.

34. Rodríguez-Morató J, Boronat A, Kotronoulas A, Pujadas M, Pastor A, Olesti E, Pérez-Mañá C, Khymenets O, Fitó M, Farré M, et al: Metabolic disposition and biological significance of simple phenols of dietary origin: Hydroxytyrosol and tyrosol. Drug Metab Rev 48: 218-236, 2016.

35. Angelis A, Hamzaoui M, Aligiannis N, Nikou T, Michailidis D, Gerolimatos P, Termentzi A, Hubert J, Halabalaki M, Renault $\mathrm{JH}$, et al: An integrated process for the recovery of high added-value compounds from olive oil using solid support free liquid-liquid extraction and chromatography techniques. J Chromatogr A 1491: 126-136, 2017.

36. Mastralexi A, Nenadis N and Tsimidou MZ: Addressing analytical requirements to support health claims on 'olive oil polyphenols' (EC Regulation 432/2012). J Agric Food Chem 62 : $2459-2461,2014$

37. Impellizzeri $\mathbf{J}$ and Lin $\mathrm{J}$ : A simple high-performance liquid chromatography method for the determination of throat-burning oleocanthal with probated antiinflammatory activity in extra virgin olive oils. J Agric Food Chem 54: 3204-3208, 2006.

38. Vougogiannopoulou K, Lemus C, Halabalaki M, Pergola C, Werz O, Smith AB III, Michel S, Skaltsounis L and Deguin B One-step semisynthesis of oleacein and the determination as a 5-lipoxygenase inhibitor. J Nat Prod 77: 441-445, 2014.

39. Singleton VL, Orthofer R and Lamuela-Raventos RM: Analysis of total phenols and other oxidation substrates and antioxidants by means of Folin-Ciocalteu reagent. Methods Enzymol 299: $152-178,1998$

40. Brand-Williams W, Cuvelier ME and Berset C: Use of a free radical method to evaluate antioxidant activity. Lebensm Wiss Technol 28: 25-30, 1995.

41. Cano A, Hernandez-Ruiz J, García-Cánovas F, Acosta M and Arnao MB: An end-point method for estimation of the total antioxidant activity in plant material. Phytochem Anal 9: 196-202, 1998.

42. Goutzourelas N, Stagos D, Demertzis N, Mavridou P, Karterolioti H, Georgadakis S, Kerasioti E, Aligiannis N, Skaltsounis L, Statiri A, et al: Effects of polyphenolic grape extract on the oxidative status of muscle and endothelial cells. Hum Exp Toxicol 33: 1099-1112, 2014.

43. Priftis A, Stagos D, Konstantinopoulos K, Tsitsimpikou C, Spandidos DA, Tsatsakis AM, Tzatzarakis MN and Kouretas D: Comparison of antioxidant activity between green and roasted coffee beans using molecular methods. Mol Med Rep 12: 7293-7302, 2015

44. Vulcano I, Halabalaki M, Skaltsounis L and Ganzera M: Quantitative analysis of pungent and anti-inflammatory phenolic compounds in olive oil by capillary electrophoresis. Food Chem 169: 381-386, 2015
45. Keiler AM,Zierau O, Bernhardt R, Scharnweber D, Lemonakis N, Termetzi A, Skaltsounis L, Vollmer G and Halabalaki M: Impact of a functionalized olive oil extract on the uterus and the bone in a model of postmenopausal osteoporosis. Eur J Nutr 53: 1073-1081, 2014

46. Angelis A, Hubert J, Aligiannis N, Michalea R, Abedini A, Nuzillard JM, Gangloff SC, Skaltsounis AL and Renault JH: Bio-guided isolation of methanol-soluble metabolites of common spruce (Picea abies) bark by-products and investigation of their dermo-cosmetic properties. Molecules 21: 21, 2016.

47. Agiomyrgianaki A, Petrakis PV and Dais P: Influence of harvest year, cultivar and geographical origin on Greek extra virgin olive oils composition: A study by NMR spectroscopy and biometric analysis. Food Chem 135: 2561-2568, 2012.

48. Pliszka B, Huszcza-Ciołkowska G and Wierzbicka E: Effects of solvents and extraction methods on the content and antiradical activity of polyphenols from fruits Actinidia arguta, Crataegus monogyna, Gaultheria procumbens and Schisandra chinensis. Acta Sci Pol Technol Aliment 15: 57-63, 2016.

49. Schlesier K, Harwat M, Böhm V and Bitsch R: Assessment of antioxidant activity by using different in vitro methods. Free Radic Res 36: 177-187, 2002.

50. Zou X, Feng Z, Li Y, Wang Y, Wertz K, Weber P, Fu Y and Liu J: Stimulation of GSH synthesis to prevent oxidative stress-induced apoptosis by hydroxytyrosol in human retinal pigment epithelial cells: Activation of Nrf2 and JNK-p62/SQSTM1 pathways. J Nutr Biochem 23: 994-1006, 2012.

51. Moi P, Chan K, Asunis I, Cao A and Kan YW: Isolation of NF-E2-related factor 2 (Nrf2), a NF-E2-like basic leucine zipper transcriptional activator that binds to the tandem NF-E2/AP1 repeat of the beta-globin locus control region. Proc Natl Acad Sci USA 91: 9926-9930, 1994.

52. Li W and Kong AN: Molecular mechanisms of Nrf2-mediated antioxidant response. Mol Carcinog 48: 91-104, 2009.

53. Nguyen T, Nioi P and Pickett CB: The Nrf2-antioxidant response element signaling pathway and its activation by oxidative stress. J Biol Chem 284: 13291-13295, 2009.

54. Kobayashi $M$ and Yamamoto M: Nrf2-Keap1 regulation of cellular defense mechanisms against electrophiles and reactive oxygen species. Adv Enzyme Regul 46: 113-140, 2006.

55. Manzanares MA, Solanas M, Moral R, Escrich R, Vela E, Costa I and Escrich E: Dietary extra-virgin olive oil and corn oil differentially modulate the mRNA expression of xenobiotic-metabolizing enzymes in the liver and in the mammary gland in a rat chemically induced breast cancer model. Eur J Cancer Prev 24: 215-222, 2015.

56. Visioli F, Wolfram R, Richard D, Abdullah MI and Crea R: Olive phenolics increase glutathione levels in healthy volunteers. J Agric Food Chem 57: 1793-1796, 2009.

57. Covas MI, Nyyssönen K, Poulsen HE, Kaikkonen J, Zunft HJ, Kiesewetter H, Gaddi A, de la Torre R, Mursu J, Bäumler H, et al; EUROLIVE Study Group: The effect of polyphenols in olive oil on heart disease risk factors: A randomized trial. Ann Intern Med 145: 333-341, 2006.

58. Procházková $\mathrm{D}$, Boušová I and Wilhelmová N: Antioxidant and prooxidant properties of flavonoids. Fitoterapia 82: 513-523, 2011.

59. Lambert JD and Elias RJ: The antioxidant and pro-oxidant activities of green tea polyphenols: A role in cancer prevention. Arch Biochem Biophys 501: 65-72, 2010.

60. Fukumoto LR and Mazza G: Assessing antioxidant and prooxidant activities of phenolic compounds. J Agric Food Chem 48: 3597-3604, 2000

61. Sakihama Y, Cohen MF, Grace SC and Yamasaki H: Plant phenolic antioxidant and prooxidant activities: Phenolics-induced oxidative damage mediated by metals in plants. Toxicology 177: 67-80, 2002.

62. Maurya DK and Devasagayam TP: Antioxidant and prooxidant nature of hydroxycinnamic acid derivatives ferulic and caffeic acids. Food Chem Toxicol 48: 3369-3373, 2010

63. Aquilano K, Baldelli S and Ciriolo MR: Glutathione: New roles in redox signaling for an old antioxidant. Front Pharmacol 5: 196, 2014.

64. Kerasioti E, Stagos D, Priftis A, Aivazidis S, Tsatsakis AM, Hayes AW and Kouretas D: Antioxidant effects of whey protein on muscle C2C12 cells. Food Chem 155: 271-278, 2014 